University of Nebraska - Lincoln

DigitalCommons@University of Nebraska - Lincoln

Faculty Publications from the Harold W. Manter Laboratory of Parasitology

1947

\title{
Andrya sciuri n. sp., a Cestode from the Northern Flying Squirrel
}

Robert L. Rausch

University of Wisconsin - Madison, rausch@u.washington.edu

Follow this and additional works at: https://digitalcommons.unl.edu/parasitologyfacpubs

Part of the Parasitology Commons

Rausch, Robert L., "Andrya sciuri n. sp., a Cestode from the Northern Flying Squirrel" (1947). Faculty Publications from the Harold W. Manter Laboratory of Parasitology. 578.

https://digitalcommons.unl.edu/parasitologyfacpubs/578

This Article is brought to you for free and open access by the Parasitology, Harold W. Manter Laboratory of at DigitalCommons@University of Nebraska - Lincoln. It has been accepted for inclusion in Faculty Publications from the Harold W. Manter Laboratory of Parasitology by an authorized administrator of DigitalCommons@University of Nebraska - Lincoln. 
Rausch in Journal of Parasitology (August 1947) v. 33, no. 4.

Copyright 1947, American Society of Parasitologists. Used by permission.

\title{
ANDRYA SCIURI N. SP., A CESTODE FROM THE NORTHERN FLYING SQUIRREL
}

\author{
Robert Rausch* \\ Department of Veterinary Science, University of Wisconsin, Madison
}

Among helminths taken from four northern flying squirrels (Glaucomys sabrinus macrotis Mearns) were two cestodes belonging to the genus Andrya. These represent an undescribed species.

The infected flying squirrels were collected in or near tamarack bogs during February, 1947, near Millston, Jackson County, Wisconsin.

Andrya sciuri n. sp.

Diagnosis: Length of strobila about $17 \mathrm{~cm}$; maximum width $2 \mathrm{~mm}$. Mature segments much broader than long, with a gradual increase in length toward posterior end of strobila, where maximum width is also attained. Ventral excretory canal averages $30 \mu$ in diameter; dorsal and transverse canals much smaller. Scolex $380 \mu$ in diameter; suckers weakly-mustled and inconspicuous, measuring about $150 \mu$ in diameter. Slight segmentation evident immediately posterior to scolex. Genital Anlagen appear typically early. Genital pores nearly all dextral; situated in posterior third of segment. Genital ducts dorsal to excretory canals. Cirrus sac muscular; averages $200 \mu$ long by $85 \mu$ wide. Medial end of cirrus sac does not reach excretory canals. Internal and external seminal vesicles well developed; latter reaches size nearly equal to that of cirrus sac. Internal seminal vesicle enlarges toward posterior end of strobila; appears to persist throughout. Cirrus unarmed. Testes 100 to 110 in number; from 40 to $50 \mu$ in diameter; not all in same plane. Testes pass lateral margins of excretory canals both porally and aporally; greater number of testes concentrated on aporal side of segment. Prostate gland absent. Vagina posterior, and at times partly ventral, to cirrus sac; large seminal receptacle appears medial to end of cirrus sac. Seminal receptacle reaches maximum size of about $420 \mu$ long by $180 \mu$ wide, after which it decreases in size, and gradually disappears. Ovary, with vitelline gland, situated at middle of segment. Development of uterus typical for genus. Terminal segments completely filled with eggs; latter measure from 52 to $56 \mu$. Embryo about $33 \mu$ long. Pyriform apparatus strongly developed.

Host: Glaucomys sabrinus macrotis Mearns (Northern Flying Squirrel).

Locality: Millston, Jackson County, Wisconsin.

Habitat: Small intestine.

Type: Two slides containing an entire specimen have been deposited in the collection of the U. S. National Museum.

\section{DISCUSSION}

Of the species of cestodes previously attributed to the genus Andrya, at least eight appear to be valid. Andrya sciuri is readily differentiated from these by the number and distribution of the testes. Andrya cuniculi (Blanchard, 1891), A. neotomae Voge, 1946, and A. monodi Joyeux and Baer, 1930, have the testes confined to the area between the longitudinal excretory canals. A. cuniculi also reaches a large size not attained by other members of the genus. In addition to the difference in arrangement, the testes are fewer (60 to 74) in $A$. neotomae and (15) in A. monodi. Andrya rhopalocephala (Riehm, 1881), A. cuniculi, and A. primordialis Douthitt, 1915, all possess well-developed prostate glands; this structure is absent in A. sciuri. Moreover, A. rhopalocephala and $A$. primordialis have fewer

Received for publication, March 17, 1947.

* This work supported in part by a grant from the Wisconsin Alumni Research Foundation. 
testes ( 75 to 80 , and 20 to 40 , respectively), and their arrangement differs from that in A. sciuri. Andrya macrocephala Douthitt, 1915, is easily differentiated from the present species by the size of the ventral excretory canals. Andrya macrocephala has fewer testes ( 43 to 57 ), and these overlap the excretory canals only on the aporal side; the scolex is also more strongly developed. Andrya africana Baer, 1933,
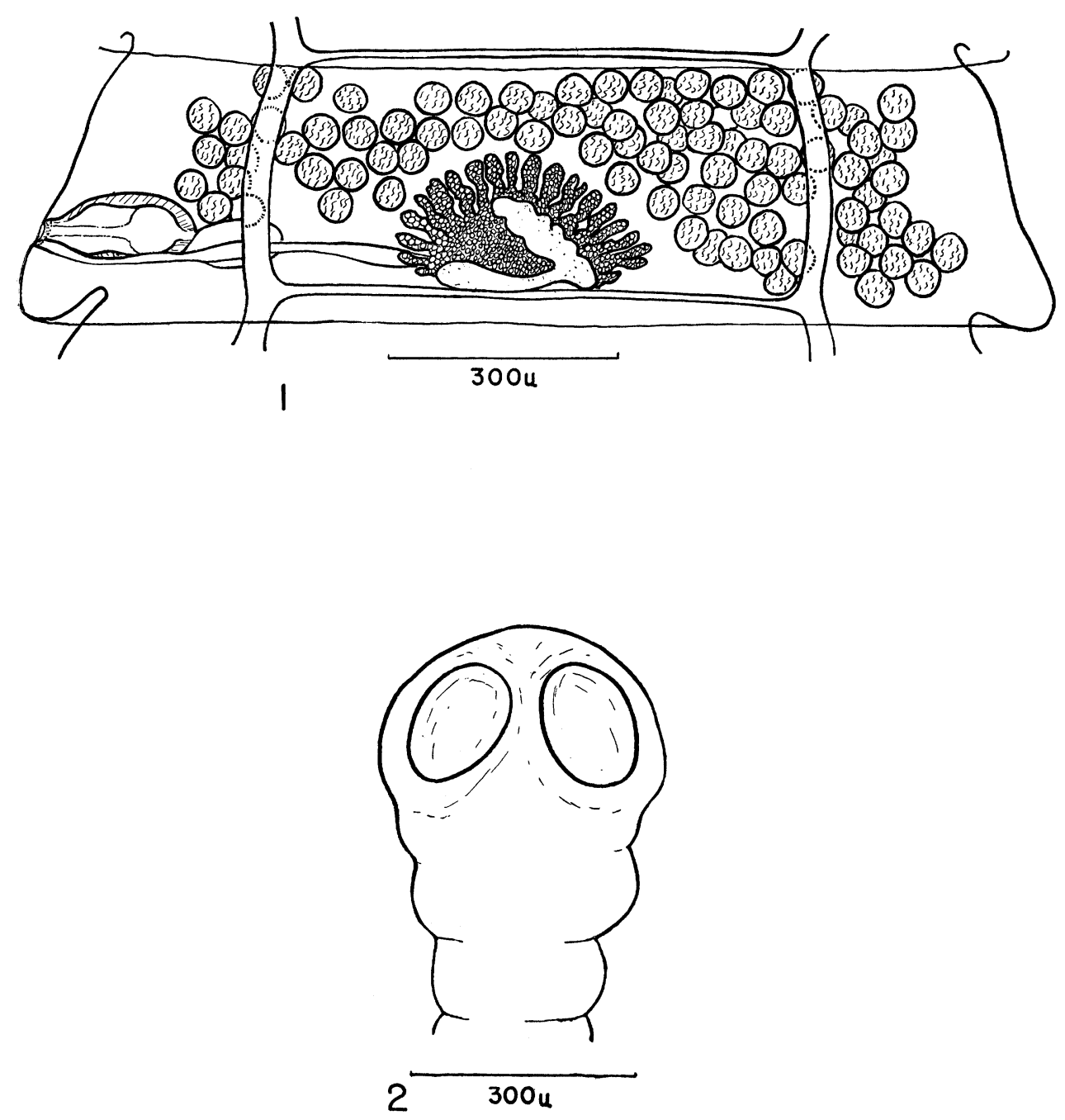

FIG. 1. A mature segment, ventral view, from Andrya sciuri.

Frg. 2. Scolex of Andrya sciuri.

has fewer testes (26 to 30 ) which nearly surround the ovary and vitelline gland, and the genital pores are unilateral. According to Baer (1927), Joyeux recognized a sub-species of $A$. primordialis, designated as $A$. primordialis var. gundii. This sub-species differs from $A$. primordialis only in number of testes (70 to 80 ) and in geographical location. The paper describing A. caucasica Kirschenblatt, 1938, was not available in the United States. The writer was advised by Dr. Charles Elton that this paper also is not available in the library of the Bureau of Animal Population, at Oxford. Andrya caucasica cannot therefore be considered in this discussion. 
Two new host records have been added by the writer for cestodes of this genus: A. macrocephala was found to be a common parasite of the eastern meadow vole (Microtus p. pennsylvanicus Ord) in both Ohio and Michigan, and a single cestode of Andrya sp. was taken from a muskrat (Ondatra z. zibethica L.) in Ohio. It is hoped that additional specimens can be obtained from the latter host, since further study is desirable in order to establish specific identity.

A key has been prepared for cestodes of the genus Andrya found in North American hosts. Four species have been recorded, all of which are easily differentiated.

\section{Key to THe NORTh AMERICAN sPeCies of Andrya}

1. Testes confined to the area between the longitudinal excretory canals . . . . 2

Testes overlapping the longitudinal excretory canals ............ 3

2. Testes 60 to 74 in number; prostate gland absent; ventral excretory canals not enlarged A. neotomae

3. Testes overlapping longitudinal excretory canals on both sides ........ 4 Testes overlapping longitudinal excretory canals on aporal side only .....5

4. Testes 100 to 110 in number; prostate gland absent; ventral excretory canals not enlarged

A. sciuri

5. Testes 20 to 40 in number; prostate gland present; ventral excretory canals not

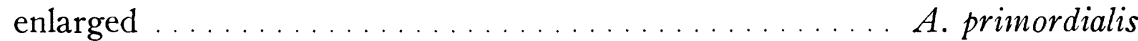

Testes 43 to 57 in number; prostate gland absent; ventral excretory canals greatly enlarged A. macrocephala

The writer wishes to take this opportunity to express indebtedness to Dr. E. W. Price for information from the files of the Bureau of Animal Industry, and to Messrs. Paul F. Springer and Alfred G. Etter, Department of Wildlife Management, University of Wisconsin, for aid in the collection of the animals from which this cestode was described.

\section{REFERENCES}

Baer, J. G. 1927 Monographie des cestodes de la famille Anoplocephalidae. Bull. Biol. France et Belgique, supp. 10. 241 pp.

1933 Contribution à l'étude de la Faune helminthologique africaine. Rev. Suisse Zool. 40: 31-84.

Douthitт, H. 1915 Studies on the cestode family Anoplocephalidae. Illinois Biol. Monogr. 1: $1-96$.

Joyeux, C. and Baer, J. G. 1930 Mission Saharienne Augiéras-Draper, 1927-1928. Cestodes. Bull. Mus. Nat. Hist. Natur. 2: 217-223.

Kirschendiatt, J. D. 1938 Die Gesetzmässigkeiten der Dynamik der Parasitenfauna bei den Mäuseähnlichen Nagetieren (Muriden) in Transkaukasien. Diss. (Univ. Leningrad) P. 87.

Voge, M. 1946 A new anoplocephalid cestode, Andrya neotomae, from the wood rat, Neotoma fuscipes. J. Parasitol. 32: 36-39. 